\title{
Políticas Públicas para o Turismo Sustentável: o caso de Armação dos Búzios - RJab
}

\author{
Bárbara Tavares de Paulac \\ Fernanda Cristina da Silva ${ }^{d}$ \\ Evandro Rodrigues de Faria
}

\section{RESUMO}

O presente estudo tem por objetivo geral analisar a dinâmica turística de uma destinação e seus efeitos para a comunidade local e, a partir dela, propor políticas públicas que visem ao turismo sustentável. Armação dos Búzios-RJ foi escolhida como unidade de análise porque representa um dos mais conhecidos, nacionalmente e internacionalmente, destinos turísticos do segmento "sol e praia" no Brasil. A base teórica do estudo contempla, principalmente, a literatura sobre políticas públicas de turismo, buscando relacionar a atuação pública à sustentabilidade da atividade. Para tanto, tomou-se por base os objetivos da política de turismo apresentados por Scott (2011). Quanto aos procedimentos metodológicos, o estudo possui natureza quantitativa e pode ser classificado como descritivo e de levantamento, sendo os dados coletados a partir da aplicação de 250 questionários junto a moradores entre dezembro de 2018 e março de 2019. Para a análise dos dados, foram utilizadas ferramentas estatísticas que permitiram validar as categorias criadas e interpretá-las. Como resultado, observou-se a necessidade de políticas públicas que promovam e ou incentivem a melhor distribuição dos benefícios e custos gerados pelo setor, melhor fornecimento de serviços básicos, a manutenção do turismo e uma relação harmoniosa entre os turistas e a população local.

Palavras-chave: Turismo sustentável; Política pública; Comunidade local; Destino turístico.

\section{ABSTRACT}

\section{Public Policies for Sustainable Tourism: the case of Armação dos Búzios - RJ}

The general objective of analyzing the tourist dynamics of a destination and its effects for the local community and, based on it, proposing public policies aimed at sustainable tourism. Armação dos Búzios-RJ was chosen as the unit of analysis because it represents one of the best known, nationally and internationally, tourist destinations in the "sun and beach" segment in Brazil. The theoretical basis of the study mainly contemplates the literature on public tourism policies, seeking to relate public performance to the sustainability of the activity. For that, it was based on the objectives of the tourism policy presented by Scott (2011). As for methodological procedures, the study has a quantitative nature and can be classified as

a. Versão preliminar apresentada no XVI Seminário Anual da Associação Nacional de Pesquisa e Pós-Graduação em Turismo 2019 - ANPTUR.

b. Pesquisa contou com apoio financeiro do CNPq, Edital PIBIC/CNPq.

c. Bacharelanda em Ciências Contábeis na Universidade Federal de Viçosa. Viçosa, Minas Gerais, Brasil. E-mail: barbaratavares1310@gmail.com

d. Doutora em Administração Pública e Governo Escola de Administração de Empresas de São Paulo da Fundação Getúlio Vargas (EAESP/FGV). Docente de Administração na Universidade Federal de Viçosa. Viçosa, Minas Gerais, Brasil. E-mail: fernanda.silva@ufv.br

e. Doutor em Administração pela Universidade Federal de Minas Gerais. Docente de Administração na Universidade Federal de Viçosa. Viçosa, Minas Gerais, Brasil. E-mail: evandrozd@hotmail.com 
descriptive and survey, with data collected from the application of 250 questionnaires to residents between December 2018 and March 2019. For data analysis, statistical tools were used to validate the categories created and interpret them. As a result, there was a need for public policies that promote and or encourage the better distribution of the benefits and costs generated by the sector, better provision of basic services, the maintenance of tourism and a harmonious relationship between tourists and the local population.

Keywords: Sustainable tourism; Public policy; Local community; Tourist destination.

\section{RESUMEN}

Políticas Públicas para el Turismo Sostenible: el caso de Armação dos Búzios - RJ

El presente estudio tiene como objetivo general analizar la dinámica turística de un destino y sus efectos para la comunidad local y, a partir de esta, proponer políticas públicas orientadas al turismo sostenible. Armação dos Búzios-RJ fue elegida como la unidad de análisis porque representa uno de los destinos turísticos más conocidos, nacional e internacionalmente, en el segmento de "sol y playa" en Brasil. La base teórica del estudio contempla principalmente la literatura sobre políticas públicas de turismo, buscando relacionar el desempeño público con la sostenibilidad de la actividad. Para eso, se basó en los objetivos de la política turística presentados por Scott (2011). En cuanto a los procedimientos metodológicos, el estudio tiene carácter cuantitativo y se puede clasificar como descriptivo y de levantamiento, con datos recolectados a partir de la aplicación de 250 cuestionariosa residentes entre diciembre de2018y marzo de 2019.Para el análisis de datos, Se utilizaron herramientas estadísticas para validar las categorías creadas e interpretarlas. Como resultado, surgió la necesidad de políticas públicas que promuevan y / o incentiven la mejor distribución de los beneficios y costos generados por el sector, una mejor provisión de servicios básicos, el mantenimiento del turismo y una relación armónica entre los turistas y la población local.

Palabras clave: Turismo sostenible; Política pública; Comunidad local; Destino turístico.

\section{INTRODUÇÃo}

O turismo é considerado um setor de grande importância no cenário socioeconômico nacional e internacional devido ao seu grande potencial de contribuição para a geração de emprego e renda e sua significativa participação no Produto Interno Bruto (PIB). Em 2018, a participação do setor no PIB nacional foi de 8,1\% (Martins, 2019).

Todavia, não obstante sua importância, sobretudo econômica, o turismo também pode acarretar impactos negativos para as destinações turísticas em diversos âmbitos - ambientais, sociais e culturais (Lickorish e Jenkins, 2000; Jenkins, 2015), devido ao crescimento predatório e insustentável deste que pode comprometer a sua função (Tulik, 1990) assim como à ausência de planejamento e ordenamento do setor (Freitas, 2002).

Nesse contexto, para que esses impactos negativos sejam minimizados, Jenkins (2015) apresenta que é necessário ter vontade política, bem como sanções legais. Hall (2004) também aponta para a necessidade de se avaliar e monitorar o setor de turismo para o seu bom desenvolvimento, o que pode ser feito por meio de políticas públicas que levem em consideração fatores ambientais, sociais, políticos e econômicos (Hall, 2004). De acordo com Beni (1999), se a atividade turística for bem planejada e administrada, tanto o turismo como o desenvolvimento regional e a proteção ambiental podem evoluir paralelamente. 
Sendo assim, "o respeito pela natureza e pelo ambiente, principalmente nas zonas costeiras e de montanha, pode fazer do turismo uma atividade lucrativa e duradoura" (Beni, 1999, p. 13). Mas o que devem fazer os administradores e planejadores locais para que os impactos negativos do turismo não sejam um fator de deterioração da destinação turística? Que medidas devem ser tomadas para que o crescimento do setor ocorra de forma sustentável?

A partir dessas indagações, e considerando a importância da atuação pública local na gestão do turismo, o presente estudo buscou analisar a dinâmica turística de uma destinação e seus efeitos para a comunidade local e, a partir dela, propor políticas públicas que visem ao turismo sustentável. À expectativa é de que este estudo subsidie discussões a respeito da importância das políticas públicas para o desenvolvimento do turismo sustentável, que sejam capazes de fomentar a atividade de modo harmonioso entre os atores envolvidos (governo, empresários, turistas, representantes da sociedade civil e moradores), considerando tanto dimensões econômicas, como sociais, culturais e ambientais.

Como unidade de análise, escolheu-se Armação dos Búzios, localizada no litoral do estado do Rio de Janeiro, visto que é uma das cidades brasileiras mais procurada por turistas de todo o mundo segundo estudos realizados pela Rede de Inteligência de Mercado no Turismo (RIMT), organização não institucional coordenada pelo Ministério do Turismo (MTur), pelo Serviço Brasileiro de Apoio às Micro e Pequenas Empresas (Sebrae Nacional) e pela Agência Brasileira de Promoção Internacional do Turismo (Embratur), que tem como objetivo compartilhar informações entre representantes do poder público, do terceiro setor e da iniciativa privada (Rede de Inteligência de Mercado no Turismo [RIMT], 2019).

Atualmente, o turismo é a principal atividade econômica da cidade, mobilizando uma grande parcela da população em torno dela. Gera diversos empregos no setor de hotelaria, gastronomia, lojas de souvenir e boutiques de diversos padrões. Porém, o crescimento desse segmento econômico gerou uma ocupação urbana desordenada em torno do centro da cidade e das áreas urbanas mais centrais ou mais próximas às principais praias e afastou os nativos para as áreas periféricas. Além da exclusão social imposta a esses atores locais (Coriolano, 2004), houve um prejuízo significativo da paisagem natural da cidade, principalmente nas áreas de praia, que são o principal fator de atração dos turistas.

Tal contexto também foi evidenciado neste estudo, que apontou caminhos (políticas públicas) para que o turismo em Búzios seja desenvolvimento de forma sustentável, o que inclui a necessidade de se pensar políticas públicas para a maior distribuição dos benefícios e custos da atividade, assim como para promover melhorias no fornecimento de serviços básicos (necessários não apenas aos moradores, mas também aos turistas), na própria realização e manutenção da atividade e na relação entre os turistas e a população local, a fim de integrar os diferentes atores que afetam e são afetados pela dinâmica turística da cidade. Tais caminhos foram apontados a partir dos objetivos da política de turismo apresentados por Scott (2011).

\section{REVISÃo DE LITERATURA}

O turismo, enquanto atividade econômica e social, tem despertado cada vez mais atenção dos gestores públicos, assim como tem sido objeto de estudo de 
várias pesquisas que se propõem a investigar as dimensões das políticas de turismo sob vários aspectos, o que se deve, principalmente, ao crescimento do setor, $\mathrm{e}$ em consequência, aos impactos positivos e negativos que acarreta (Airey, 2015).

Segundo Goeldner, Ritchie e Mcintosh (2002, p. 294), a política de turismo pode ser definida como:

Um conjunto de regulamentações, regras, diretrizes, diretivas, objetivos e estratégias de desenvolvimento e promoção que fornece uma estrutura na qual são tomadas as decisões coletivas e individuais que afetam diretamente o desenvolvimento turístico e as atividades diárias dentro de uma destinação.

Nesse cenário, segundo os referidos autores, as políticas públicas de turismo devem buscar tanto maximizar os benefícios oriundos da atividade, quanto minimizar os seus efeitos negativos.

Para que isto ocorra, as políticas públicas de turismo devem estabelecer estratégias de planejamento, identificando os problemas e as possíveis soluções em relação ao turismo, envolvendo o maior número de atores locais possível nesse processo, a fim de se obter uma política que vise à inclusão social e ao turismo sustentável (Cruz, 2000).

Importante destacar que, conforme apontado por Lickorish e Jenkins (2000, p.221), "a política de turismo não é um plano de turismo, mas sim o ponto de referência em relação às decisões de planejamento que devem ser relacionadas". Assim, conforme os referidos autores, o planejamento deve propor ações que levam ao alcance dos objetivos estabelecidos na política. Scott (2011), a partir de exemplos da literatura, sistematiza os objetivos e papéis da política de turismo, que teriam como meta o desenvolvimento econômico, social, ambiental e político como um todo, que seriam coordenação, planejamento, legislação, apoio empreendedor, estímulo, promoção, turismo social e proteção ao interesse público.

Embora haja a expectativa de que as políticas públicas contribuam para a promoção do turismo sustentável, está não é uma tarefa simples. Primeiro porque não há um entendimento comum sobre o que seja turismo sustentável ( Swarbrooke, 1999; Jenkins, 2015). Como salientado por Jenkins (2015), apesar de bem intencionado, o termo sustentabilidade oferece pouca orientação sobre como esta poderá ser alcançada. Além disso, os impactos de mais longo prazo, como os ambientais e socioculturais, são mais difíceis de serem controlados do que os impactos mais imediatos, como os econômicos, e isso acaba gerando uma dificuldade para se ter um equilíbrio entre essas dimensões.

Não obstante, conforme Swarbrooke (1999), é fundamental que a definição de turismo sustentável considere elementos ambientais, sociais e econômicos. Assim, o autor o define como o "turismo economicamente viável, mas que não destrói os recursos de que dependerá o futuro do turismo, nomeadamente o ambiente físico e o tecido social da comunidade anfitriã". (Swarbrooke, 1999, p.13). De forma semelhante, o Ministério do Turismo, define o turismo sustentável como "a atividade que satisfaz as necessidades dos visitantes e as necessidades socioeconômicas das regiões receptoras, enquanto os aspectos culturais, a integridade dos ambientes naturais e a diversidade biológica são mantidos para o futuro" (Ministério do Turismo, 2016, p. 7). 
Turismo sustentável também envolve:

(...) compreensão dos impactos turísticos; distribuição justa de custos e benefícios; geração de empregos locais diretos e indiretos; fomento de negócios lucrativos; injeção de capital com consequente diversificação da economia local; interação com todos os setores e segmentos da sociedade; desenvolvimento estratégico e logístico de modais de transporte; encorajamento ao uso produtivo de terras tidas como marginais (turismo no espaço rural); subvenções para os custos de conservação ambiental (Beni, 2003, p.14).

Considerando as definições apresentadas acima, nota-se que é de suma importância preservar ambientalmente, economicamente e socialmente as destinações turísticas, para que o crescimento do turismo não acarrete em perda da função turística devido aos problemas ambientais e sociais gerados. Para tanto, o Ministério do Turismo propõe que quatro dimensões sejam consideradas: a sustentabilidade ambiental, a sustentabilidade sociocultural, a sustentabilidade econômica e a sustentabilidade político-institucional (Ministério do Turismo, 2009).

A sustentabilidade ambiental prioriza a manutenção do meio ambiente e a segura utilização dos recursos naturais; a sustentabilidade sociocultural valoriza os aspectos culturais da população na tentativa de preservar a cultura local e os valores morais do povo nativo, não permitindo que o turismo enfraqueça a identidade da sociedade em que ele se faz presente; a sustentabilidade econômica visa ao desenvolvimento econômico associado à gestão de recursos que garantam a equidade na distribuição da renda gerada com a atividade turística; e a sustentabilidade político-institucional assegura a conservação das parcerias entre os agentes governamentais e os atores sociais (Ministério do Turismo, 2016).

Essas quatro dimensões são complementares e, portanto, precisam ser consideradas conjuntamente nas políticas públicas de turismo, para que a atividade seja desenvolvida de forma sustentável. Porém, conforme Dodds e Butler (2010), a implementação de políticas sustentáveis enfrenta algumas barreiras, tanto por parte do setor público como do privado. Essas barreiras, segundo os autores, vão desde "confrontos de poder entre partidos políticos a nível nacional à falta de envolvimento das partes interessadas e transparência a nível local", sendo a barreira mais comumente encontrada a priorização da dimensão econômica - que gera resultados mais imediatos, em detrimento de dimensões sociais e ambientais. De forma similar, Dodds (2007) também já tinha sinalizado que interesses econômicos têm sido priorizados nas políticas de turismo, deixando de lado questões sociais e ambientais.

Apesar dessas barreiras, o setor público pode e deve atuar no desenvolvimento do turismo sustentável. Swarbrooke (1999) apresenta vários meios pelos quais essa atuação pode ocorrer, dentre eles, destaca-se: "legislação e regulamentação"; "financiamento e incentivos fiscais", "planejamento do uso da terra"; "provisão de infraestrutura"; "designação de áreas de proteção especial"; "controle do governo sobre o número de turistas", e outros.

$\mathrm{Na}$ tentativa de relacionar os objetivos da política de turismo com as dimensões da sustentabilidade, a partir de Scott (2011), apresenta-se a Quadro 1: 
Quadro 1 - Objetivos da Política de Turismo e relação com a Sustentabilidade

\begin{tabular}{|c|c|c|}
\hline $\begin{array}{l}\text { Objetivos e Papéis da } \\
\text { Política de Turismo }\end{array}$ & $\begin{array}{l}\text { Estabelecimento do poder da } \\
\text { Atuação Governamental para } \\
\text { atingir os objetivos desejados }\end{array}$ & $\begin{array}{l}\text { Dimensões da } \\
\text { Sustentabilidade segundo } \\
\text { o Ministério do Turismo }\end{array}$ \\
\hline $\begin{array}{l}\text { Desenvolvimento } \\
\text { econômico }\end{array}$ & $\begin{array}{l}\text { Incentivos que visem o crescimento } \\
\text { da economia regional/local. }\end{array}$ & $\begin{array}{l}\text { Sustentabilidade } \\
\text { Econômica }\end{array}$ \\
\hline Competitividade & $\begin{array}{l}\text { Garantir a competitividade } \\
\text { saudável, a fim de manter a } \\
\text { prosperidade das destinações } \\
\text { turísticas. }\end{array}$ & $\begin{array}{l}\text { Sustentabilidade } \\
\text { Econômica }\end{array}$ \\
\hline Prosperidade Local & $\begin{array}{l}\text { Associação do desenvolvimento } \\
\text { local com o desenvolvimento do } \\
\text { turismo, de forma a incentivar as } \\
\text { atividades locais ligadas ao turismo. }\end{array}$ & $\begin{array}{l}\text { Sustentabilidade } \\
\text { Econômica }\end{array}$ \\
\hline Qualidade de emprego & $\begin{array}{l}\text { Maximizar a oferta e a qualidade } \\
\text { de empregos locais no setor de } \\
\text { turismo, a partir do valor do salário } \\
\text { e das condições de trabalho. }\end{array}$ & $\begin{array}{l}\text { Sustentabilidade } \\
\text { Econômica }\end{array}$ \\
\hline Equidade social & $\begin{array}{l}\text { Inclusão da comunidade menos } \\
\text { favorecida economicamente } \\
\text { no processo produtivo do } \\
\text { setor de turismo, garantindo } \\
\text { melhor distribuição de renda e } \\
\text { benefícios sociais. }\end{array}$ & $\begin{array}{l}\text { Sustentabilidade } \\
\text { Econômica e Sociocultural }\end{array}$ \\
\hline Atendimento ao visitante & $\begin{array}{l}\text { Priorização da segurança e } \\
\text { satisfação dos visitantes e } \\
\text { moradores, sem qualquer tipo de } \\
\text { discriminação. }\end{array}$ & $\begin{array}{l}\text { Sustentabilidade } \\
\text { Econômica e Sociocultural }\end{array}$ \\
\hline Controle local & $\begin{array}{l}\text { Inclusão da população na tomada } \\
\text { de decisões e empoderamento } \\
\text { social dos atores locais. }\end{array}$ & $\begin{array}{l}\text { Sustentabilidade Político- } \\
\text { institucional }\end{array}$ \\
\hline Bem-estar da comunidade & $\begin{array}{l}\text { Garantir a melhoria da qualidade } \\
\text { de vida da comunidade, a partir da } \\
\text { infraestrutura local e acesso aos } \\
\text { recursos básicos, para que sejam } \\
\text { minimizados os efeitos negativos } \\
\text { do turismo, como o tráfego e a } \\
\text { falta de água. }\end{array}$ & $\begin{array}{l}\text { Sustentabilidade } \\
\text { Sociocultural }\end{array}$ \\
\hline Riqueza cultural & $\begin{array}{l}\text { Manter a integridade cultural do } \\
\text { local, respeitando as tradições } \\
\text { culturais e os valores sociais locais. }\end{array}$ & $\begin{array}{l}\text { Sustentabilidade } \\
\text { Sociocultural }\end{array}$ \\
\hline Integridade Física & $\begin{array}{l}\text { Manutenção dos aspectos físicos } \\
\text { da cidade, tanto das paisagens } \\
\text { naturais quanto das artificiais. }\end{array}$ & Sustentabilidade Ambiental \\
\hline Diversidade Biológica & $\begin{array}{l}\text { Garantir a conservação do meio } \\
\text { ambiente e da natureza local, da } \\
\text { biodiversidade. }\end{array}$ & Sustentabilidade Ambiental \\
\hline Eficiência de recursos & $\begin{array}{l}\text { Gestão eficiente de recursos básicos, } \\
\text { como energia e geração de lixo. }\end{array}$ & Sustentabilidade Ambiental \\
\hline
\end{tabular}


Quadro 1 - Continuação.

\begin{tabular}{|c|c|c|}
\hline $\begin{array}{l}\text { Objetivos e Papéis da } \\
\text { Política de Turismo }\end{array}$ & $\begin{array}{l}\text { Estabelecimento do poder da } \\
\text { Atuação Governamental para } \\
\text { atingir os objetivos desejados }\end{array}$ & $\begin{array}{l}\text { Dimensões da } \\
\text { Sustentabilidade segundo } \\
\text { o Ministério do Turismo }\end{array}$ \\
\hline Pureza ambiental & $\begin{array}{l}\text { Minimização da poluição do ar, da } \\
\text { água e da terra. }\end{array}$ & Sustentabilidade Ambiental \\
\hline Sustentabilidade & $\begin{array}{l}\text { Proteção do meio ambiente e da } \\
\text { sociedade em suas diferentes } \\
\text { esferas. }\end{array}$ & $\begin{array}{l}\text { Sustentabilidade Ambiental } \\
\text { e Sociocultural }\end{array}$ \\
\hline $\begin{array}{l}\text { Política Internacional de } \\
\text { boa vontade e paz }\end{array}$ & Busca e cultura da paz. & $\begin{array}{l}\text { Sustentabilidade Político- } \\
\text { institucional e Sociocultural }\end{array}$ \\
\hline
\end{tabular}

É possível verificar o uso da sistematização de Scott (2011) também no artigo de Souza, Emmendoerfer e Knupp (2017), em um contexto de análise das políticas públicas de turismo no desenvolvimento ambiental em um estado federativo, São Paulo. Neste estudo, entretanto, a sistematização de Scott (2011) será utilizada como base para a proposição políticas públicas de turismo para Armação dos Búzios, com vistas à atuação sustentável.

Importante ressaltar que essa proposição se dará a partir da percepção dos moradores, ou seja, da comunidade local, considerados atores-chave para o desenvolvimento do turismo sustentável. Considerar tais atores nesse processo é fundamental porque, como apontado por Freitas (2002), "a ideologia do Turismo Sustentável traz na sua base a preocupação com a conservação do meio físico e das formas de organização das comunidades receptoras, seus usos, costumes e tradições, assim como a sua participação nas fases de planejamento".

Tal planejamento deve considerar as preferências e desejos da comunidade local e resultar na sua melhoria (Friedgen, 1991). Assim, a partir da proposição da Quadro 1, os objetivos da política de turismo, que considere as dimensões da sustentabilidade, devem ser alcançados por meio de ações definidas no planejamento do turismo, que por sua vez, deve ser construído a partir do interesse das partes interessadas, em especial da comunidade local.

\section{ARMAÇÃo dos BÚzIos}

Armação dos Búzios está localizada no sudeste do estado do Rio de Janeiro e faz fronteira apenas com a cidade de Cabo Frio e o Oceano Atlântico, tratando-se de uma península. Segundo o Instituto Brasileiro de Geografia e Estatística (IBGE, 2018), a população foi estimada em pouco mais de 32 mil habitantes no censo de 2017 com o maior PIB per capita da microrregião, cerca de $\mathrm{R} \$ 53$ mil.

Ainda segundo o IBGE, em 2017 a cidade apresentava 89,6\% de domicílios com esgotamento sanitário adequado e, quando comparado com outros municípios do estado, ocupa a posição 12 de 92 e a taxa de escolarização de 6 a 14 anos de idade é de 97,6\%. E, de acordo com a Prefeitura Municipal, a principal atividade econômica da cidade é o turismo, seguido pela pesca, que já foi a principal fonte de renda do município. 
Entre os anos de 1989 e 1995 nasceu um movimento separatista forte financiado por comerciantes e composto por membros da sociedade. Tal movimento conseguiu, em novembro de 1995, a emancipação de Cabo Frio - RJ. Apesar de, ainda, existir certa dependência que, nos últimos anos, está sendo suprida pelo crescimento do centro comercial e pelos serviços básicos oferecidos pelo município de Búzios.

Levantamentos preliminares indicaram que diversos atores locais são influenciados de alguma forma com a dinâmica local do turismo da cidade, sendo os moradores, comerciantes ou não, os principais atingidos. Em campo, além desses atores, identificou-se que outros, como a Associação Comercial e Empresarial de Búzios (ACEB), e atores sociais não organizados, como os próprios turistas e proprietários de casas de veraneio, também influenciam e são influenciados por esta dinâmica. As instituições públicas municipais, como a Prefeitura e as Secretarias, especificamente a de Turismo e Meio Ambiente e Saneamento são aquelas que podem, de forma mais direta, interferir na gestão pública do turismo, minimizando os efeitos negativos e maximizando os efeitos positivos do setor, a principal fonte de renda da cidade.

O município é uma destinação turística muito procurada por pessoas de diversos estados do país e, inclusive, de outros países também, sendo um dos destinos mais visitado do Brasil segundo estudos realizados pela Rede de Inteligência de Mercado no Turismo (RIMT, 2019). Possui 23 praias, que são o principal atrativo turístico da cidade, e outros pontos turísticos relevantes, como a Rua das Pedras, a Orla Bardot e o Porto da Barra. Os bairros que compõem a cidade podem ser observados na Figura 1, que mostra os limites territoriais de Búzios, com os bairros peninsulares e continentais.

Figura 1 - Localização dos bairros de Armação dos Búzios

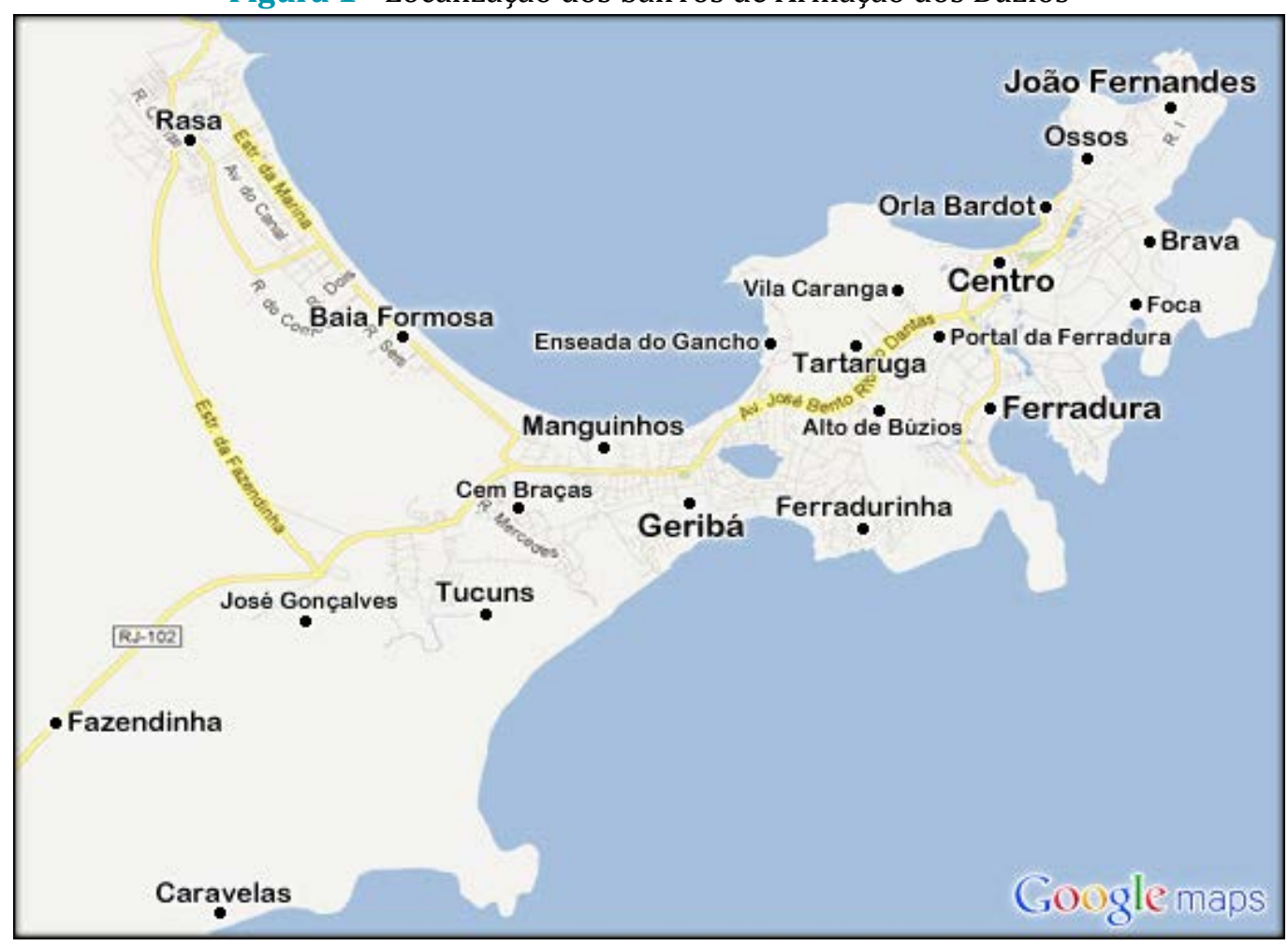

Fonte - O Outro Lado do Rio (n.d.). (online) 
Essa figura permite melhor entendimento dos bairros da cidade e da influência da dinâmica turística na distribuição do espaço. Os bairros peninsulares centrais, onde há predominância de turistas [e atrativos turísticos] em relação a moradores, são os mais atingidos pelo turismo por serem a principal área turística da cidade e são, principalmente, Centro, João Fernandes, Ossos, Brava, Ferradura, Tartaruga e Geribá.

Os bairros periféricos, principalmente Cem Braças, Rasa, José Gonçalves e Tucuns, são atingidos indiretamente pelo turismo e é para onde os nativos foram afastados, conforme Coriolano (2004) aponta como sendo uma das principais consequências do turismo, não sendo bairros comumente frequentados pelos visitantes. Já os bairros comerciais, principalmente Manguinhos, abrigam maior concentração do comércio que visa atender aos moradores e a alguns segmentos turísticos, sendo o espaço em que os turistas e moradores se misturam.

\section{PROCEDIMENTOS METODOLÓGICOS}

A presente pesquisa classifica-se como de natureza predominantemente quantitativa, porque buscou, por meio de instrumentos estruturados, especificamente questionários, analisar a dinâmica turística de Búzios-RJ na a percepção dos atores locais por meios numéricos. Segundo Sampieri, Collado e Lucio (2006, p. 5), a pesquisa quantitativa é utilizada "(...) para testar hipóteses com base na medição numérica e na análise estatística para estabelecer padrões de comportamento".

No que se refere aos seus objetivos, este estudo se classifica como descritivo, pois busca apresentar como se dá a dinâmica turística de Búzios, em relação à percepção dos efeitos do turismo, aos objetivos da política de turismo e à dinâmica sustentável. Para Gil (2002), uma das características principais deste tipo de pesquisa é o uso de procedimentos padronizados de coleta de dados, tais como questionário e observação sistemática.

Quanto aos meios de investigação, a pesquisa se classifica como de levantamento, tendo em vista que analisou, a partir de questionários aplicados in loco, entre dezembro de 2018 e março de 2019, a opinião dos moradores sobre o fenômeno investigado. Conforme definição apresentada por Gil (2002, p. 50) o estudo de levantamento é caracterizado pela "interrogação direta das pessoas cujo comportamento se deseja conhecer".

O questionário foi composto por perguntas correspondentes às características do respondente e de questões do tipo escala Likert para a elaboração de constructos de acordo com a literatura apresentada. Para testar a confiabilidade dos constructos foi testada pelo Alfa de Cronbach que, de acordo com Hair et al. (2009) é capaz de revelar o grau em que os itens de um instrumento são homogêneos e refletem um determinado constructo implícito. 0 coeficiente Alfa de Cronbach varia entre 0,00 e 1,00 , sendo os valores de 0,60 a 0,70 considerados o limite inferior de aceitabilidade.

Foi também utilizada a análise de conglomerados (cluster analysis) que, segundo Hair et al. (2009), é um conjunto de técnicas estatísticas que tem como objetivo agrupar dados heterogêneos segundo suas características, formando grupos ou conglomerados homogêneos. A análise de Clusters foi utilizada com o propósito de agrupar os atores em grupos específicos, buscando entender se existem grupos mais afetados ou excluídos que devem ser alvos das políticas. Toda a análise estatística foi feita através do uso do software estatístico IBM SPSS®. 
Foram aplicados 250 questionários junto aos moradores de Armação dos Búzios, nas ruas e nos diferentes bairros da cidade. Na estratégia de coleta de dados utilizou-se amostra aleatória, estatisticamente significativa, sugerida por Triola (2017). Considerando que a população de Búzios no ano de 2019 foi igual a 33.870 e o nível de confiança escolhido foi de $95 \%$, pode-se verificar que o erro máximo associado foi de 5,9\%. 0 erro máximo está de acordo com a margem estabelecida pelo autor, que afirma que em Ciências Sociais Aplicadas admite-se erros próximos a 5\%.

As categorias (constructos) criadas para análise da dinâmica do turismo e dos seus efeitos na cidade estudada, que emergiram do campo, associadas na seção de resultados à proposição de Scott (2011), são descritas no Quadro 2.

\section{Quadro 2 - Caracterização das categorias}

\begin{tabular}{|c|c|c|c|}
\hline Categorias & Descriçãa & Categorias & Descrição \\
\hline $\begin{array}{l}\text { Imagem da } \\
\text { Cidade }\end{array}$ & $\begin{array}{l}\text { Avalia a satisfação em } \\
\text { relação à cidade e o quanto } \\
\text { a cultura local é associada } \\
\text { à imagem externa que é } \\
\text { propagada. }\end{array}$ & $\begin{array}{l}\text { Aspectos } \\
\text { econômicos }\end{array}$ & $\begin{array}{l}\text { Avalia o impacto econômico } \\
\text { que o turismo exerce na renda } \\
\text { da população, o quanto de } \\
\text { emprego ele gera, o quão justa é a } \\
\text { distribuição dessa renda gerada, } \\
\text { as condições de trabalho no setor } \\
\text { e o custo de vida da cidade em } \\
\text { relação a outras cidades. }\end{array}$ \\
\hline $\begin{array}{l}\text { Imagem do } \\
\text { Turismo }\end{array}$ & $\begin{array}{l}\text { Avalia se o turismo é ou } \\
\text { não benéfico para a cidade } \\
\text { na visão dos moradores } \\
\text { e o quanto a comunidade } \\
\text { percebe esse benefício. }\end{array}$ & $\begin{array}{l}\text { Impactos do } \\
\text { Turismo }\end{array}$ & $\begin{array}{l}\text { Avalia os impactos do turismo } \\
\text { na estrutura física da cidade, } \\
\text { na preservação ambiental, no } \\
\text { tráfego, na limpeza urbana, na } \\
\text { superlotação da cidade e nas } \\
\text { relações sociais. }\end{array}$ \\
\hline $\begin{array}{l}\text { Participação } \\
\text { Social }\end{array}$ & $\begin{array}{l}\text { Avalia se há parceria entre } \\
\text { o governo e população para } \\
\text { a manutenção do turismo, } \\
\text { assim como o nível de } \\
\text { participação popular na } \\
\text { tomada de decisões em } \\
\text { relação a essa atividade. }\end{array}$ & $\begin{array}{l}\text { Serviços } \\
\text { públicos }\end{array}$ & $\begin{array}{l}\text { Avalia a qualidade dos serviços } \\
\text { de saúde, educação, segurança, } \\
\text { distribuição de água, alimentação, } \\
\text { transporte, telefonia e } \\
\text { fornecimento de energia elétrica. }\end{array}$ \\
\hline
\end{tabular}

Fonte - Adaptado de Scott (2011).

\section{RESULTADOS E DISCUSSÃo}

\section{Caracterização dos respondentes}

Nesta seção, apresenta-se uma breve caracterização dos participantes deste estudo, com a finalidade de entender o perfil dos moradores da cidade de Armação dos Búzios para, a partir disso, propor melhorias em sua relação com o governo e com os turistas.

Constatou-se que $42 \%$ dos respondentes possuía entre 19 e 29 anos, $19 \%$ entre 30 e 39 anos, $20 \%$ entre 40 e 49 anos e 19\% possuía 50 anos ou mais. Além disso, uma parcela significativa dos respondentes, cerca de $47 \%$, possuía até o Ensino Médio completo. 0 restante estava dividido em 18\% com Ensino Fundamental, 11\% com Ensino Superior Incompleto, 23\% com Ensino Superior 
Completo e nenhum com Pós-graduação. Esses dados indicam um nível regular de formação acadêmica, o que pode ser associado à falta de universidades públicas na região e ao pouco número de faculdades privadas, não havendo nenhuma na própria cidade.

Associando a idade dos respondentes ao grau de escolaridade, tem-se que, das 58 pessoas que possuem ensino superior completo, 33 tem 30 anos ou menos; e das 164 pessoas que possuem apenas ensino fundamental ou ensino médio, 106 já possuem mais de 30 anos, mostrando que é recente a tendência de formação superior após o ensino médio dentre os moradores participantes da pesquisa.

A Tabela 1 mostra o local de origem dos respondentes.

Tabela 1- Local de origem dos respondentes

\begin{tabular}{|l|c|}
\hline \multicolumn{1}{|c|}{ Local de Origem } & Número de pessoas \\
\hline Armação dos Búzios & 134 \\
\hline Rio de Janeiro (cidade) & 44 \\
\hline Rio de Janeiro (estado) & 22 \\
\hline Outros estados do Brasil & 11 \\
\hline Buenos Aires & 39 \\
\hline Total & $\mathbf{2 5 0}$ \\
\hline \multicolumn{2}{|c|}{ Fonte - dados da pesquisa } \\
\hline
\end{tabular}

Pode-se observar que há muitos moradores respondentes que nasceram em Búzios ou que, devido à falta de hospital até pouco depois da emancipação do município, nasceram em Cabo Frio. Mas que sempre moraram na cidade, podendo ser chamados de nativos. Há também muitos moradores respondentes oriundos da capital do estado, a cidade do Rio de Janeiro.

Além disso, é interessante ressaltar o grande número de moradores respondentes que vieram de Buenos Aires, em um efeito massivo de imigração em torno da década de 1970 até início dos anos 2000 devido à crise econômica da Argentina, sendo, atualmente, detentores de uma porção significativa do comércio e da hotelaria, além de ainda serem turistas com poder aquisitivo alto (Barbosa, 2003).

A Tabela 2 mostra a renda familiar mensal dos respondentes.

Tabela 2 - Renda familiar mensal dos moradores respondentes

\begin{tabular}{|l|c|}
\hline \multicolumn{1}{|c|}{ Renda familiar mensal } & $\begin{array}{c}\text { Número de } \\
\text { pessoas }\end{array}$ \\
\hline Até 1 salário mínimo & 6 \\
\hline De 1 a 3 salários mínimos & 84 \\
\hline De 3 a 6 salários mínimos & 55 \\
\hline De 6 a 9 salários mínimos & 49 \\
\hline De 9 a 12 salários mínimos & 22 \\
\hline Mais de 12 salários mínimos & 34 \\
\hline Total & $\mathbf{2 5 0}$ \\
\hline \multicolumn{2}{|c|}{ Fonte - dados da pesquisa } \\
\hline
\end{tabular}


Pode-se observar que $58 \%$ dos respondentes possuem renda familiar mensal de até 6 salários mínimos, $28 \%$ possuem renda entre 9 e 12 salários mínimos e $14 \%$ possuem renda acima de 12 salários, sendo que $11 \%$ dos respondentes mora sozinho, 9\% moram com uma pessoa apenas, 40\% com duas ou três pessoas e $40 \%$ moram com quatro pessoas ou mais. Todavia, das pessoas que possuem renda inferior a 3 salários mínimos, 29\% moram com quatro pessoas ou mais e $18 \%$ das pessoas que possuem renda acima de 12 salários mínimos moram com três pessoas ou menos, o que mostra uma má distribuição da renda dentre os respondentes.

O Gráfico 1 e a Tabela 3 mostram, respectivamente, a distribuição de respondentes e a caracterização deles por bairro, tendo em vista que, para a aplicação dos questionários, foram escolhidos os bairros que melhor representam a área com maior e menor incidência de turismo.

\section{Gráfico 1 - Número de respondentes por bairro}

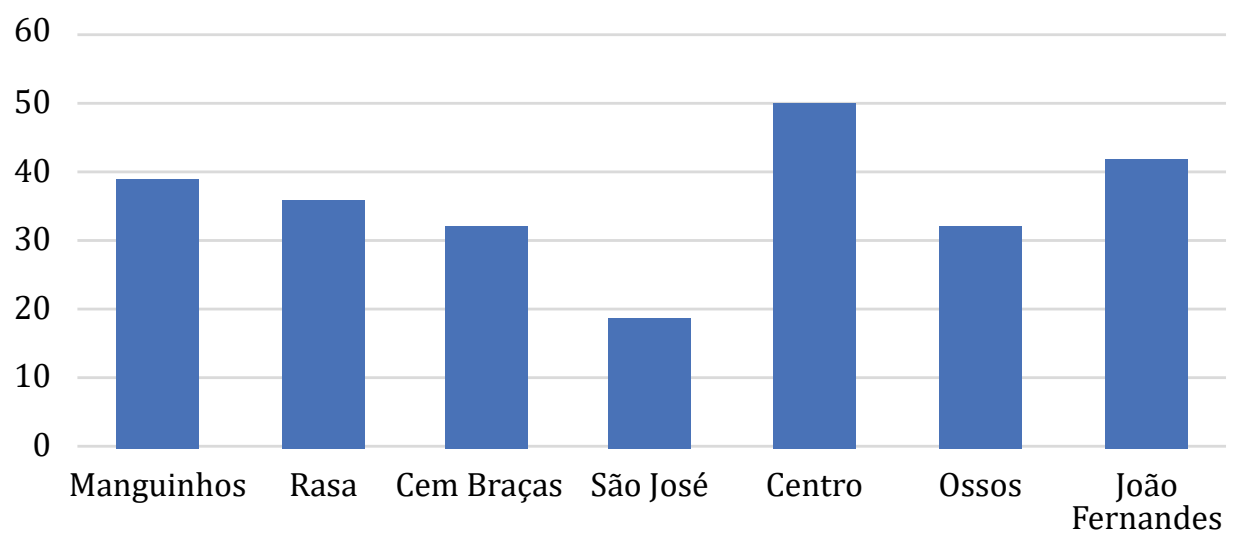

Fonte - dados da pesquisa

Tabela 3 - Caracterização dos respondentes por bairro

\begin{tabular}{|l|l|l|l|}
\hline Bairros & $\begin{array}{l}\text { Grau de } \\
\text { Escolaridade médio }\end{array}$ & $\begin{array}{l}\text { Tempo médio de } \\
\text { moradia médio }\end{array}$ & $\begin{array}{l}\text { Renda familiar mensal } \\
\text { média }\end{array}$ \\
\hline Manguinhos & Ensino Médio & 21 anos & De 1 a 3 salários mínimos \\
\hline Rasa & Ensino Médio & 27 anos & De 1 a 3 salários mínimos \\
\hline Cem Braças & Ensino Fundamental & 37 anos & De 1 a 3 salários mínimos \\
\hline São José & Ensino Fundamental & 41 anos & De 1 a 3 salários mínimos \\
\hline Centro & Ensino Médio & 20 anos & De 6 a 9 salários mínimos \\
\hline Ossos & Ensino Médio & 29 anos & Mais de 12 salários mínimos \\
\hline João Fernandes & Ensino Médio & 24 anos & Mais de 12 salários mínimos \\
\hline
\end{tabular}

Fonte - dados da pesquisa

Pode-se observar que há diferenças significativas no perfil dos respondentes de acordo com o bairro de residência. E, tendo em vista o mapa da cidade apresentado no tópico 3 do presente trabalho e os bairros tidos como centrais ou periféricos, é possível perceber que aqueles em que há menor incidência de 
turismo há também menor grau de escolaridade, um tempo maior de moradia e menor renda familiar, como em Cem Braças e São José.

Nos bairros centrais, devido à localização privilegiada em relação à oferta de serviços e concentração de renda gerada pelo turismo, residem aqueles cujo grau de escolaridade e renda familiar é maior, como é o caso do Centro, dos Ossos e de João Fernandes. Além disso, é possível notar que a renda familiar nos Ossos e em João Fernandes é ainda maior do que a do Centro, o que pode ser percebido pela alta especulação imobiliária da área e pelo grande número de residências dos donos de hotéis e restaurantes da cidade.

Pode-se também perceber que o tempo de moradia médio dos respondentes que residem nos bairros periféricos é maior, indicando que há uma predominância de moradores nativos nessas áreas, o que pode ser visto como um efeito da dinâmica turística que afasta os nativos dos principais pontos turísticos, a fim de que haja mais espaço e estrutura turística para os visitantes. Essa situação também eleva o custo de vida do entorno da área turística, reservando os espaços de moradia dessa área para os residentes com maior poder aquisitivo.

Em destinações predominantemente turísticas, como é o caso de Armação dos Búzios, os residentes com maior poder aquisitivo são aqueles que estão mais intimamente ligados com o setor de turismo e são proprietários dos serviços ofertados para os visitantes. E, para atestar essa diferença significativa na percepção dos respondentes de acordo com o bairro de residência, gerou-se a tabela 6 que indica a disposição dos bairros agrupados pela análise de cluster, feita através do software estatístico IBM SPSS® de acordo com as categorias construídas.

Tabela 4 - Disposição dos bairros pela análise de cluster

\begin{tabular}{|c|c|c|c|c|c|}
\hline \multicolumn{2}{|c|}{ Número de Cluster do caso } & \multirow{2}{*}{$\begin{array}{c}\text { Frequência } \\
8\end{array}$} & \multirow{2}{*}{$\begin{array}{l}\text { Percentual } \\
\qquad 8,7\end{array}$} & \multirow{2}{*}{$\begin{array}{c}\text { Percentual válido } \\
\qquad 8,7\end{array}$} & \multirow{2}{*}{$\begin{array}{c}\text { Percentual } \\
\text { cumulativo } \\
443,5\end{array}$} \\
\hline \multirow{6}{*}{1} & Centro & & & & \\
\hline & João Fernandes & 41 & 43,5 & 43,5 & 87,0 \\
\hline & Manguinhos & 11 & 12,0 & 12,0 & 98,9 \\
\hline & Ossos & 32 & 34,8 & 34,8 & 34,8 \\
\hline & Rasa & 1 & 1,1 & 1,1 & 100,0 \\
\hline & Total & 93 & 100,0 & 100,0 & \\
\hline \multirow{7}{*}{2} & Cem Braças & 32 & 20,4 & 20,4 & 20,4 \\
\hline & Centro & 42 & 26,8 & 26,8 & 47,1 \\
\hline & João Fernandes & 1 & 6 & 6 & 47,8 \\
\hline & Manguinhos & 28 & 17,8 & 17,8 & 65,6 \\
\hline & Rasa & 35 & 22,3 & 22,3 & 87,9 \\
\hline & São José & 19 & 12,1 & 12,1 & 100,0 \\
\hline & Total & 157 & 100,0 & 100,0 & \\
\hline
\end{tabular}

Fonte - dados da pesquisa

Percebe-se, portanto, que os bairros que foram analisados anteriormente como sendo de maior poder aquisitivo, João Fernandes e Ossos, se encontram no primeiro cluster, com uma pequena porcentagem dos residentes do Centro e de Manguinhos. 
Já no segundo cluster se encontram os respondentes de bairros periféricos, como Cem Braças, Rasa e São José, juntamente com uma parte do Centro e de Manguinhos.

0 fato de o Centro se encontrar majoritariamente no segundo cluster, apesar da localização, deve-se ao maior impacto sofrido pela dinâmica turística, visto que é a área mais afetada tanto ambientalmente quanto socialmente, gerando uma percepção pior em relação aos impactos. As Tabelas 5 e 6 indicam o grau de escolaridade e a renda familiar mensal dos respondentes agrupados pela análise de cluster.

Tabela 5 - Disposição do grau de escolaridade pela análise de cluster

\begin{tabular}{|c|c|c|c|c|c|}
\hline \multicolumn{2}{|r|}{ Número de Cluster do caso } & Frequência & Percentual & $\begin{array}{c}\text { Percentual } \\
\text { válido }\end{array}$ & $\begin{array}{l}\text { Percentual } \\
\text { cumulativo }\end{array}$ \\
\hline \multirow{5}{*}{1} & Ensino Fundamental & 1 & 1,1 & 1,1 & 1,1 \\
\hline & Ensino Médio & 48 & 51,1 & 51,1 & 52,2 \\
\hline & Ensino Superior Completo & 35 & 38,0 & 38,0 & 90,2 \\
\hline & Ensino Superior Incompleto & 9 & 9,8 & 9,8 & 100,0 \\
\hline & Total & 93 & 100,0 & 100,0 & \\
\hline \multirow{5}{*}{2} & Ensino Fundamental & 45 & 28,7 & 28,7 & 28,7 \\
\hline & Ensino Médio & 70 & 44,6 & 44,6 & 73,2 \\
\hline & Ensino Superior Completo & 23 & 14,6 & 14,6 & 87,9 \\
\hline & Ensino Superior Incompleto & 19 & 12,1 & 12,1 & 100,0 \\
\hline & Total & 157 & 100,0 & 100,0 & \\
\hline
\end{tabular}

Fonte - dados da pesquisa

Tabela 6 - Disposição da renda familiar mensal pela análise de cluster

\begin{tabular}{|l|c|c|c|c|}
\hline Número de Cluster do caso & Frequência & Percentual & $\begin{array}{c}\text { Percentual } \\
\text { válido }\end{array}$ & $\begin{array}{c}\text { Percentual } \\
\text { cumulativo }\end{array}$ \\
\hline Até 1 salário mínimo & 1 & 1,1 & 1,1 & 1,1 \\
\hline De 1 a 3 salários mínimos & 8 & 8,7 & 8,7 & 9,8 \\
\hline De 3 a 6 salários mínimos & 11 & 12,0 & 12,0 & 21,7 \\
\hline De 6 a 9 salários mínimos & 22 & 23,9 & 23,9 & 45,7 \\
\hline De 9 a 12 salários mínimos & 20 & 21,7 & 21,7 & 67,4 \\
\hline Mais De 12 salários mínimos & 31 & 32,6 & 32,6 & 100,0 \\
\hline Total & 93 & 100,0 & 100,0 & \\
\hline Até 1 salário mínimo & 5 & 3,2 & 3,2 & 3,2 \\
\hline De 1 a 3 salários mínimos & 76 & 48,4 & 48,4 & 51,6 \\
\hline De 3 a 6 salários mínimos & 44 & 28,0 & 28,0 & 79,6 \\
\hline De 6 a 9 salários mínimos & 27 & 17,2 & 17,2 & 96,8 \\
\hline De 9 a 12 salários mínimos & 2 & 1,3 & 1,3 & 98,1 \\
\hline Mais De 12 salários mínimos & 3 & 1,9 & 1,9 & 100,0 \\
\hline Total & 157 & 100,0 & 100,0 & \\
\hline
\end{tabular}

Fonte - dados da pesquisa

Observa-se, portanto, como analisado anteriormente, que no primeiro cluster, formado principalmente por moradores dos bairros João Fernandes e Ossos, 
encontram-se agrupados os respondentes com maior grau de escolaridade, ensino médio e ensino superior, e maior renda familiar mensal, majoritariamente acima de 6 salários mínimos.

0 segundo cluster, no entanto, formado principalmente por residentes dos bairros periféricos e por alguns residentes dos bairros centrais, mas que são diretamente atingidos pelos impactos do turismo, encontram-se os respondentes com menor grau de escolaridade, ensino fundamental e ensino médio, e menor renda familiar mensal, majoritariamente até 6 salários mínimos.

\section{Análise das categorias}

Para a análise da confiabilidade das categorias utilizadas nesta pesquisa foi calculado o Alfa de Cronbach de cada uma delas, através também do software estatístico IBM SPSS®. Isso tendo em vista que o arranjo feito das variáveis leva em consideração a literatura utilizada no trabalho a fim de identificar a percepção dos moradores em relação ao turismo. E, a partir dessa percepção, propor políticas públicas que visem ao aperfeiçoamento da dinâmica turística da cidade. A Tabela 7 aponta os coeficientes obtidos em cada categoria.

Tabela 7 - Alfa de Cronbach para categorias consideradas na pesquisa

\begin{tabular}{|l|c|}
\hline \multicolumn{1}{|c|}{ Categoria } & Alfa de Cronbach \\
\hline Imagem da Cidade & 0,739 \\
\hline Imagem do Turismo & 0,732 \\
\hline Participação Social & 0,918 \\
\hline Aspectos Econômicos & 0,708 \\
\hline Impactos do Turismo & 0,843 \\
\hline Serviços & 0,828 \\
\hline
\end{tabular}

Fonte - dados da pesquisa

Atestada a confiabilidade dos constructos construídos, obteve-se a Tabela 8 que apresenta a resposta mínima e máxima, a média, o desvio padrão e a variância das respostas de cada categoria obtidas nos 250 questionários aplicados para os moradores de Armação dos Búzios - RJ.

Ressalta-se que a escala utilizada revela o grau de sustentabilidade percebida pelos moradores respondentes. Então quanto maior for a média, em uma escala de 1 a 6, mais sustentável o turismo é percebido pelos respondentes nas diferentes categorias analisadas.

Tabela 8 - Estatística Descritiva

\begin{tabular}{|l|c|c|c|c|c|c|}
\hline Categorias & N & Mínimo & Máximo & Média & Desvio Padrão & Variância \\
\hline Imagem da Cidade & 250 & 2,50 & 6,00 & 4,5550 &, 90665 &, 822 \\
\hline $\begin{array}{l}\text { Imagem do } \\
\text { Turismo }\end{array}$ & 250 & 2,00 & 6,00 & 5,1240 &, 81473 &, 664 \\
\hline
\end{tabular}


Tabela 8 - Continuação.

\begin{tabular}{|l|c|c|c|c|c|c|}
\hline Categorias & $\mathbf{N}$ & Mínimo & Máximo & Média & Desvio Padrão & Variância \\
\hline $\begin{array}{l}\text { Participação } \\
\text { Social }\end{array}$ & 250 & 1,00 & 3,50 & 1,2760 &, 67946 &, 462 \\
\hline $\begin{array}{l}\text { Aspectos } \\
\text { Econômicos }\end{array}$ & 250 & 2,09 & 5,36 & 3,8262 &, 65058 &, 423 \\
\hline $\begin{array}{l}\text { Impactos do } \\
\text { Turismo }\end{array}$ & 250 & 1,20 & 5,80 & 4,0548 & 1,05879 & 1,121 \\
\hline Serviços & 250 & 1,40 & 5,00 & 3,2840 &, 97263 &, 946 \\
\hline Total de casos & 250 & & & & & \\
\hline
\end{tabular}

Fonte - dados da pesquisa

Pode-se observar que as médias obtidas revelam uma percepção dos respondentes boa em relação à imagem da cidade e ainda melhor em relação à imagem do turismo. Porém, é preciso notar que há uma variância significativa nas respostas, o que será abordado na avaliação dos constructos por bairro e pela disposição dos clusters. Além disso, percebe-se que há percepção de baixa participação social na gestão local do turismo sendo, inclusive, menos discrepante a diferença de percepção entre os respondentes.

Quanto aos aspectos econômicos, os dados da pesquisa evidenciam que há uma percepção positiva em relação ao impacto do turismo na renda da população e na geração de empregos na cidade. Porém, a distribuição da renda gerada não é considerada justa e o custo de vida da cidade é considerado alto em relação a outras cidades, gerando uma média regular para a categoria como um todo.

Apesar de o custo de vida da cidade ser considerado alto, é importante salientar que grande parte dos moradores respondentes considera que o poder aquisitivo dos turistas caiu nos últimos anos e que é necessário que haja medidas que incentivem visitas de turistas de maior nível econômico, mostrando incoerência no pensamento dos residentes que acreditam ser necessário aumentar o preço dos produtos e serviços a fim de "melhorar o padrão do turismo".

Os impactos do turismo também são medidos em nível de sustentabilidade, ou seja, quanto menor for a média obtida menos sustentável é o turismo em relação aos seus impactos e, quanto maior for essa média, então mais sustentável é esse setor nesse aspecto. Pode-se perceber, portanto, que os impactos do turismo para a cidade ainda não se configuram como um problema público grave, mas que precisa ser amenizado.

A variância obtida se deve à discrepância entre os impactos ambientais e infraestruturais, uma vez que apesar de o ar da cidade não ser percebido como poluído e a natureza ser considerada preservada, o tráfego é considerado intenso, a limpeza pública é considerada insatisfatória e a cidade é considerada superlotada em épocas de alta temporada.

A percepção dos moradores respondentes em relação aos serviços é regular, demonstrando ser um dos aspectos que exige maior atenção, visto o alto nível de insatisfação com a educação e saúde pública. Todavia, a média dos respondentes em relação ao transporte público e à segurança na cidade é positiva, apesar de haver uma preocupação de que a violência esteja aumentando gradativamente. Outro aspecto que precisa ser foco da gestão pública local é a distribuição de 
água e fornecimento de energia elétrica, que são percebidos como muito prejudicados na alta temporada, devido ao intenso fluxo de turistas na cidade.

A Tabela 9 mostra as médias obtidas em cada categoria de acordo com o bairro de residência dos respondentes.

Tabela 9 - Avaliação das categorias por bairro

\begin{tabular}{|l|c|c|c|c|c|c|}
\hline Bairros & $\begin{array}{c}\text { Imagem } \\
\text { da Cidade }\end{array}$ & $\begin{array}{c}\text { Imagem do } \\
\text { Turismo }\end{array}$ & $\begin{array}{c}\text { Participação } \\
\text { Social }\end{array}$ & $\begin{array}{c}\text { Aspectos } \\
\text { Econômicos }\end{array}$ & $\begin{array}{c}\text { Impactos } \\
\text { do Turismo }\end{array}$ & Serviços \\
\hline Manguinhos & 5,05 & 4,84 & 1,32 & 3,74 & 3,53 & 3,27 \\
\hline Rasa & 4,63 & 4,31 & 1,09 & 3,16 & 3,28 & 2,50 \\
\hline Cem Braças & 3,28 & 5,39 & 1 & 3,52 & 4,15 & 2,78 \\
\hline São José & 3,12 & 5,41 & 1 & 3,56 & 4,05 & 2,73 \\
\hline Centro & 5,33 & 5,53 & 1 & 3,74 & 3,20 & 2,82 \\
\hline Ossos & 4,64 & 5,26 & 1,55 & 4,49 & 5,27 & 4,36 \\
\hline João & 4,67 & 5,17 & 1,76 & 4,43 & 5,23 & 4,34 \\
\hline Fernandes & & & & & & \\
\hline
\end{tabular}

Fonte - dados da pesquisa

E a Tabela 10 mostra as médias obtidas em cada categoria de acordo com cada cluster formado.

Tabela 10 - Média por categoria na análise de cluster

\begin{tabular}{|l|c|c|}
\hline \multirow{2}{*}{ Constructos } & \multicolumn{2}{|c|}{ Cluster } \\
\hline Imagem da Cidade & $\mathbf{1}$ & $\mathbf{2}$ \\
\hline Imagem do Turismo & 4,76 & 4,44 \\
\hline Participação Social & 5,32 & 5,01 \\
\hline Aspectos Econômicos & 1,65 & 1,05 \\
\hline Impactos do Turismo & 4,46 & 3,45 \\
\hline Serviços & 5,15 & 3,40 \\
\hline \multicolumn{2}{|c|}{ Fonte - dados da pesquisa } \\
\end{tabular}

É possível observar que os bairros com maior poder aquisitivo e maior grau de escolaridade, que se encontram no primeiro cluster. Eles têm percepção mais positiva do turismo e da cidade, além de perceberem maior participação social na gestão pública local e maior impacto do turismo na economia municipal.

Todavia, a maior diferença na percepção dos respondentes na formação dos clusters é em relação aos impactos do turismo para a cidade e na qualidade percebida dos serviços. Aqueles que se encontram no primeiro cluster percebem menos os impactos provocados pela dinâmica turística e consideram os serviços públicos mais satisfatórios. Em comparação com os que se encontram no segundo cluster, que possuem menor poder aquisitivo, menor grau de escolaridade e residem em bairros periféricos.

Associando a percepção dos respondentes quanto às categorias analisadas aos objetivos e papéis da política de turismo propostos por Scott (2011), é possível identificar, na Tabela 11, em quais áreas o governo deve atuar, por meio de políticas públicas, para que o turismo seja desenvolvido de forma sustentável. 
Tabela 11 - Proposição de Scott (2011) e a sustentabilidade do turismo em Armação dos Búzios

\begin{tabular}{|c|c|c|c|}
\hline $\begin{array}{l}\text { Objetivos e } \\
\text { Papéis da } \\
\text { Política de } \\
\text { Turismo }\end{array}$ & $\begin{array}{l}\text { Categorias } \\
\text { analisadas } \\
\text { no estudo }\end{array}$ & $\begin{array}{l}\text { Percepção dos respondentes quanto a } \\
\text { questões relacionadas aos objetivos e papeis } \\
\text { da Política de Turismo }\end{array}$ & $\begin{array}{l}\text { Áreas de } \\
\text { políticas } \\
\text { públicas } \\
\text { necessárias }\end{array}$ \\
\hline $\begin{array}{l}\text { Desenvolvimento } \\
\text { econômico }\end{array}$ & $\begin{array}{l}\text { Aspectos } \\
\text { econômicos }\end{array}$ & $\begin{array}{l}\text { A população em geral acredita que o } \\
\text { turismo impacta positivamente a renda das } \\
\text { famílias, porém é preciso que haja propostas } \\
\text { governamentais que visem à manutenção do } \\
\text { turismo e ao crescimento da economia do setor. }\end{array}$ & Trabalho \\
\hline Competitividade & $\begin{array}{l}\text { Aspectos } \\
\text { econômicos }\end{array}$ & $\begin{array}{l}\text { A competitividade está sendo predominante entre } \\
\text { as grandes empresas, dificultando a ascensão } \\
\text { dos empreendedores locais devido ao menor } \\
\text { custo dos produtos comercializados por aquelas } \\
\text { e à dificuldade de manutenção dos negócios de } \\
\text { menor porte durante a baixa temporada. }\end{array}$ & Trabalho \\
\hline $\begin{array}{l}\text { Prosperidade } \\
\text { Local }\end{array}$ & $\begin{array}{l}\text { Aspectos } \\
\text { econômicos }\end{array}$ & $\begin{array}{l}\text { Com o desenvolvimento do turismo, os } \\
\text { empreendedores locais estão sendo substituídos } \\
\text { por grandes empresas e franquias, reduzindo a } \\
\text { geração de renda direta para o município e para } \\
\text { a população, havendo maior desenvolvimento } \\
\text { turístico do que das atividades locais. }\end{array}$ & Trabalho \\
\hline $\begin{array}{l}\text { Qualidade de } \\
\text { emprego }\end{array}$ & $\begin{array}{l}\text { Aspectos } \\
\text { econômicos }\end{array}$ & $\begin{array}{l}\text { As condições de trabalho no setor do turismo } \\
\text { foram avaliadas como insatisfatórias devido } \\
\text { à elevada carga horária em épocas de maior } \\
\text { movimento turístico e à percepção de salário não } \\
\text { correspondente à renda gerada pelos visitantes. } \\
\text { Além disso, foi considerada como uma das } \\
\text { únicas fontes de oferta de emprego na cidade, } \\
\text { excetuando-se trabalhos na prefeitura, e que só é } \\
\text { suficiente para a demanda da população durante } \\
\text { o verão, sem carteira assinada ou quaisquer } \\
\text { benefícios legais. }\end{array}$ & Trabalho \\
\hline Equidade social & $\begin{array}{l}\text { Serviços } \\
\text { públicos }\end{array}$ & $\begin{array}{l}\text { Bairros periféricos como a Rasa, Cem Braças e } \\
\text { São José percebem negativamente os serviços } \\
\text { da cidade, como educação, saúde, transporte, } \\
\text { segurança, distribuição de água e fornecimento } \\
\text { de energia elétrica. Residentes desses bairros } \\
\text { apontam maior dificuldade de locomoção } \\
\text { durante a alta temporada devido à falta de opção } \\
\text { de transportes públicos e ao tráfego intenso na } \\
\text { avenida principal da cidade. Além disso, apontam } \\
\text { maior preocupação em relação à segurança e } \\
\text { ao crescimento da violência e se sentem muito } \\
\text { prejudicados com a distribuição de água durante } \\
\text { o verão, alegando que ficam sem o recurso por } \\
\text { vários dias em favorecimento das áreas turísticas } \\
\text { da cidade. Não se sentem representados pelas } \\
\text { políticas públicas de turismo e não consideram } \\
\text { justa a distribuição de renda gerada pelo setor, } \\
\text { percebendo a atividade turística benéfica } \\
\text { predominantemente para a elite da cidade. }\end{array}$ & $\begin{array}{l}\text { Educação; } \\
\text { Saúde; } \\
\text { Transporte; } \\
\text { Segurança; } \\
\text { Assistência } \\
\text { social; } \\
\text { Moradia. }\end{array}$ \\
\hline
\end{tabular}


Tabela 11 - Continuação.

\begin{tabular}{|c|c|c|c|}
\hline $\begin{array}{l}\text { Objetivos e } \\
\text { Papéis da } \\
\text { Política de } \\
\text { Turismo }\end{array}$ & $\begin{array}{l}\text { Categorias } \\
\text { analisadas } \\
\text { no estudo }\end{array}$ & $\begin{array}{l}\text { Percepção dos respondentes quanto a } \\
\text { questões relacionadas aos objetivos e papeis } \\
\text { da Política de Turismo }\end{array}$ & $\begin{array}{l}\text { Áreas de } \\
\text { políticas } \\
\text { públicas } \\
\text { necessárias }\end{array}$ \\
\hline $\begin{array}{l}\text { Atendimento ao } \\
\text { visitante }\end{array}$ & $\begin{array}{l}\text { Imagem da } \\
\text { cidade e } \\
\text { Imagem do } \\
\text { Turismo }\end{array}$ & $\begin{array}{l}\text { A priorização da segurança e satisfação } \\
\text { dos visitantes é percebida como foco da } \\
\text { gestão pública local, porém os residentes } \\
\text { não percebem os próprios moradores como } \\
\text { priorizados por essa gestão. }\end{array}$ & $\begin{array}{l}\text { Segurança; } \\
\text { Lazer; } \\
\text { Cultura. }\end{array}$ \\
\hline Controle local & $\begin{array}{l}\text { Participação } \\
\text { social }\end{array}$ & $\begin{array}{l}\text { É evidente a percepção de baixa participação } \\
\text { social na gestão local do turismo dentre } \\
\text { os respondentes, principalmente, entre } \\
\text { aqueles que residem em bairros periféricos. } \\
\text { É possível notar também uma percepção } \\
\text { maior de participação social dos moradores } \\
\text { de João Fernandes, o que pode ser entendido } \\
\text { pela presença majoritária de grandes } \\
\text { empreendedores locais que residem nesse } \\
\text { bairro e, por sua vez, possuem maior } \\
\text { poder aquisitivo e têm mais contato com } \\
\text { representantes do governo. }\end{array}$ & $\begin{array}{l}\text { Inclusão } \\
\text { social; } \\
\text { Participação } \\
\text { popular. }\end{array}$ \\
\hline $\begin{array}{l}\text { Bem-estar da } \\
\text { comunidade }\end{array}$ & $\begin{array}{l}\text { Serviços } \\
\text { públicos }\end{array}$ & $\begin{array}{l}\text { A infraestrutura local é percebida como } \\
\text { insatisfatória para os moradores em } \\
\text { favorecimento das áreas turísticas e os serviços } \\
\text { e acesso aos recursos básicos são considerados } \\
\text { insuficientes para a demanda local, o que torna } \\
\text { os efeitos negativos do turismo, como o tráfego } \\
\text { e a falta de água, mais perceptíveis durante } \\
\text { a alta temporada, principalmente para os } \\
\text { moradores da Rasa, Cem Braças e São José. }\end{array}$ & $\begin{array}{l}\text { Infraestrutura; } \\
\text { Educação; } \\
\text { Saúde; } \\
\text { Transporte; } \\
\text { Segurança. }\end{array}$ \\
\hline Riqueza cultural & $\begin{array}{l}\text { Imagem da } \\
\text { cidade }\end{array}$ & $\begin{array}{l}\text { Os respondentes não demonstraram conhecer } \\
\text { a história da cidade e reconhecer uma cultura } \\
\text { local, com exceção daqueles que disseram } \\
\text { ser de famílias tradicionalmente buzianas } \\
\text { e sentirem falta da exaltação da pesca e de } \\
\text { quilombos importantes no município. Todavia, } \\
\text { não atribuíram ao turismo a falta de destaque } \\
\text { dos valores sociais locais. }\end{array}$ & Cultura \\
\hline $\begin{array}{l}\text { Integridade } \\
\text { Física }\end{array}$ & $\begin{array}{l}\text { Impactos } \\
\text { do turismo } \\
\text { e Serviços } \\
\text { públicos }\end{array}$ & $\begin{array}{l}\text { Os aspectos físicos da cidade, tanto as paisagens } \\
\text { naturais quanto as artificiais, são percebidos } \\
\text { como preservados, porém foi ressaltada a } \\
\text { necessidade de obras públicas que melhorem } \\
\text { o calçamento das ruas internas da cidade e das } \\
\text { construções de obras públicas para os serviços } \\
\text { básicos, como saúde e educação. }\end{array}$ & $\begin{array}{l}\text { Infraestrutura; } \\
\text { Meio } \\
\text { ambiente. }\end{array}$ \\
\hline $\begin{array}{l}\text { Diversidade } \\
\text { Biológica }\end{array}$ & $\begin{array}{l}\text { Impactos do } \\
\text { turismo }\end{array}$ & $\begin{array}{l}\text { A conservação do meio ambiente e da natureza } \\
\text { local não foi enfatizada como uma necessidade } \\
\text { pública urgente, porém a existência de lixo e } \\
\text { escoamento de esgoto em algumas praias foi } \\
\text { considerado alarmante para os respondentes, } \\
\text { principalmente, os que vivem no Centro da } \\
\text { cidade e em Manguinhos, um bairro comercial } \\
\text { e residencial que possui no entorno praias com } \\
\text { muita movimentação turística. }\end{array}$ & $\begin{array}{l}\text { Meio } \\
\text { ambiente; } \\
\text { Saneamento } \\
\text { básico. }\end{array}$ \\
\hline
\end{tabular}

(continua...) 
Tabela 11 - Continuação.

\begin{tabular}{|c|c|c|c|}
\hline $\begin{array}{l}\text { Objetivos e } \\
\text { Papéis da } \\
\text { Política de } \\
\text { Turismo }\end{array}$ & $\begin{array}{l}\text { Categorias } \\
\text { analisadas } \\
\text { no estudo }\end{array}$ & $\begin{array}{l}\text { Percepção dos respondentes quanto a } \\
\text { questões relacionadas aos objetivos e papeis } \\
\text { da Política de Turismo }\end{array}$ & $\begin{array}{l}\text { Áreas de } \\
\text { políticas } \\
\text { públicas } \\
\text { necessárias }\end{array}$ \\
\hline $\begin{array}{l}\text { Eficiência de } \\
\text { recursos }\end{array}$ & $\begin{array}{l}\text { Aspectos } \\
\text { econômicos } \\
\text { e Impactos } \\
\text { do turismo }\end{array}$ & $\begin{array}{l}\text { A gestão de recursos básicos, como energia e } \\
\text { geração de lixo, não foi considerada eficiente, } \\
\text { devido à insatisfação com a limpeza urbana e } \\
\text { reclamação quanto à falta de recursos hídricos e } \\
\text { elétricos durante o verão nos bairros periféricos } \\
\text { e no centro da cidade, aonde o sinal de telefone } \\
\text { também é prejudicado pela grande concentração } \\
\text { de turistas, principalmente à noite. }\end{array}$ & $\begin{array}{l}\text { Saneamento } \\
\text { básico; } \\
\text { Infraestrutura. }\end{array}$ \\
\hline $\begin{array}{l}\text { Pureza } \\
\text { ambiental }\end{array}$ & $\begin{array}{l}\text { Impactos do } \\
\text { turismo }\end{array}$ & $\begin{array}{l}0 \text { ar não foi considerado poluído e as praias são } \\
\text { percebidas como preservadas, com exceção das } \\
\text { praias do Centro, aonde há grande presença } \\
\text { de barcos de passeio, que foram consideradas } \\
\text { prioritárias de atenção da gestão local, } \\
\text { inclusive visando à manutenção do turismo e } \\
\text { atratividade da cidade. }\end{array}$ & $\begin{array}{l}\text { Saneamento } \\
\text { básico; } \\
\text { Infraestrutura; } \\
\text { Meio } \\
\text { ambiente. }\end{array}$ \\
\hline Sustentabilidade & $\begin{array}{l}\text { Impactos do } \\
\text { turismo }\end{array}$ & $\begin{array}{l}\text { Percebeu-se como prioridades a melhoria da } \\
\text { coleta de lixo na cidade, a regulamentação } \\
\text { das redes de esgoto, a inserção social dos } \\
\text { moradores na dinâmica turística com melhor } \\
\text { distribuição da renda gerada nesse setor e a } \\
\text { melhoria dos serviços básicos para a população. }\end{array}$ & $\begin{array}{l}\text { Saneamento } \\
\text { básico; } \\
\text { Assistência } \\
\text { social; } \\
\text { Infraestrutura; } \\
\text { Meio } \\
\text { ambiente; } \\
\text { Educação; } \\
\text { Saúde; } \\
\text { Segurança; } \\
\text { Transporte. }\end{array}$ \\
\hline $\begin{array}{l}\text { Política } \\
\text { Internacional } \\
\text { de boa vontade } \\
\text { e paz }\end{array}$ & $\begin{array}{l}\text { Não } \\
\text { analisado }\end{array}$ & Busca e cultura da paz. & $\begin{array}{l}\text { Relações } \\
\text { públicas. }\end{array}$ \\
\hline
\end{tabular}

Fonte - Elaborado pelos autores a partir de Scott (2011)

A partir dos resultados, sugere-se que a gestão pública local do turismo na cidade de Armação dos Búzios tenha como foco o bem-estar da população para que o turismo continue sendo rentável para o município e cresça em harmonia com os moradores, que devem ser inseridos na dinâmica turística, a fim de se manter o turismo de forma sustentável.

\section{CONSIDERAÇÕES FINAIS}

De modo geral, a pesquisa revelou que os moradores respondentes de Armação dos Búzios a consideram uma ótima cidade para se viver e veem o turismo como parte fundamental da economia local, acreditando que ele é responsável pela maior parte dos empregos existentes. Apesar disso, não consideram 
justa a distribuição de renda gerada pela atividade turística, pois percebem a priorização da alocação de recursos nos bairros centrais em detrimento dos bairros periféricos, onde residem a maior parte dos moradores.

Durante a alta temporada, entre os meses de dezembro até o feriado de Carnaval, e em alguns feriados prolongados durante o ano, os moradores respondentes percebem o aumento da oferta de empregos. Porém, com condições insatisfatórias, devido à majoração da carga horária diária e à falta de regularidade na contratação de mão de obra. Além disso, acreditam ter pouca oferta de emprego durante os meses de baixa temporada.

Além disso, os moradores respondentes consideram que o turismo é benéfico para a cidade e que seus impactos ainda não se tornaram predatórios. Porém, percebem a importância da atenção da gestão pública local para o manejamento do tráfego; coleta de lixo mais eficiente; manejamento das redes de esgoto de forma a não poluir as praias; melhoria dos serviços básicos, principalmente educação e saúde; e reforço da segurança nos bairros periféricos.

Ademais, sente-se a necessidade de melhor distribuição de água e fornecimento de energia elétrica durante o verão; criação de empregos em outros setores da economia; melhoria das condições de trabalho no setor turístico; incentivo para as atividades locais e ascensão de pequenos empreendedores; valorização da cultura local; e abertura para maior participação social na tomada de decisões relacionadas à gestão pública local.

Como sugestão de pesquisas futuras, sugere-se estudos qualitativos que busquem analisar a dinâmica do turismo em outras cidades litorâneas que possuam o turismo como principal fonte de renda para comparar com a realidade observada em Armação dos Búzios. E estudos quantitativos que analisem a percepção dos outros atores locais importantes na dinâmica do turismo na cidade estudada.

\section{REFERÊNCIAS}

Airey, D. (2015). Developments in understanding tourism policy, Tourism Review, vol. 70 n. 4, pp. 246-258.

Barbosa, K. C. (2003). Turismo em Armação dos Búzios (RJ/Brasil): Percepções locais sobre os problemas da cidade e diretrizes prioritárias de apoio à gestão ambiental. Dissertação de Mestrado (Mestrado em Ciência Ambiental) - Niterói: Universidade Federal Fluminense.

Beni, M. C. (1999). Política e estratégia do desenvolvimento regional: Planejamento integrado e sustentável do turismo. Revista Turismo em Análise. v. 10. n. 1. p. 7-17.

Beni, M. C. (2003). Como certificar o turismo sustentável?. Revista Turismo em Análise, v. 14 , n. 2, p. 5-16.

Coriolano, L. N. M. T. (2004). 0 turismo, a exclusão e a inclusão social. Revista da casa da geografia de sobral (RCGS), v. 6, n. 1.

Cruz, R. C. (2000). Política de turismo e território. São Paulo: Contexto.

Dodds, R. (2007) Sustainable Tourism Policy—Rejuvenation or a Critical Strategic Initiative. Anatolia, 18:2, 277-298. 
Dodds, R., \& Butler, R. W. (2010). Barriers to implementing sustainable tourism policy in mass tourism destinations. Tourisms: An International Multidisciplinary. Journal of Tourism, 5(1), 35-53.

Freitas, C. M. (2002). Diretrizes para o turismo sustentável em municípios. São Paulo: Roca.

Gil, A. C. (2002). Como elaborar projetos de pesquisa. 4a ed. São Paulo: Atlas.

Fridgen, J. D. (1991). Dimensions of tourism. East Lansing, Michigan: Educational Institute. American Hotel \& Motel Association.

Goeldner, C. R., Ritchie, J. R. B., \& Mcintosh, R. W. (2002). Turismo: princípios, práticas e filosofias. 8. ed. Porto Alegre: Bookman.

Hair, J. F., Anderson, R. E., Tatham, R. L., \& Black, W. C. (2009). Análise multivariada de dados. 6a ed. Porto Alegre: Bookman.

Hall, C. M. (2004). Planejamento turístico: políticas, processos e relacionamentos, 2ed. São Paulo: Contexto.

IBGE - Instituto Brasileiro de Geografia e Estatística (2018). Cidades - Armação dos Búzios. Recuperado de: https://cidades.ibge.gov.br/brasil/rj/armacao-dos-buzios/panorama. Acesso em: 25 abr. 2018.

Jenkins, C. L. (2015). Tourism policy and planning for developing countries: some critical issues. Tourism Recreation Research, 40:2, 144-156.

Lickorish, L. J., Jenkins, C. L. (2000). Introdução ao Turismo. Trad. Vasconcelos, F. C. S. Rio de Janeiro: Campus.

Ministério do Turismo. (2009). Programa de Regionalização do Turismo - Roteiros do Brasil. Turismo e sustentabilidade. Brasília: MTUR.

Ministério do Turismo. (2016). Turismo e sustentabilidade. Brasília: MTUR.

O Outro Lado do Rio (n.d.). Localização. Referenciado de: https://regiaodoslagos1f2013. wordpress.com/localizacao/. Acesso em: 20 jun. 2020.

Rede de Inteligência de Mercado no Turismo. (2019). Boletim de inteligência de mercado no turismo: motivação de viagem e grupo de viagem do turista internacional. $4 \mathrm{a}$ ed. Brasília: MTUR.

Martins, A. (2019). Cresce a participação do Turismo no PIB nacional. Recuperado de :http://www.turismo.gov.br/\%C3\%BAltimas-not\%C3\%ADcias/12461-cresce-aparticipa\%C3\%A7\%C3\%A3o-do-turismo-no-pib-nacional.html. Acesso em: 10 ago. 2019.

Sampieri, R. H., Collado, C. F., \& Lucio, P. B. (2006). Metodologia de pesquisa. 3a ed. São Paulo: McGraw-Hill.

Scott, N. (2011). Tourism Policy: A Strategic Review. Contemporary tourism review. Goodfellow Publishers Limited, Woodeaton, Oxford.

Souza, C. O., Emmendoerfer, M. L., \& Knupp, M. E. C. G. (2017). Questão ambiental: dimensão periférica em política pública de turismo?. Revista Turismo em Análise. v. 28. n. 1. p. $450-473$.

Swarbrooke, J. (1999). Sustainable tourism management. Oxon: Cab International.

Triola, M. F. (2017). Introdução à estatística. 12a ed. Rio de Janeiro: Editora LTC.

Tulik, O. (1990). Turismo e repercussões no espaço geográfico. Revista Turismo em Análise, v. 1, n. 2, p. 63-77. 


\section{CONTRIBUIÇÕES}

Bárbara Tavares de Paula: Definição do problema de pesquisa e objetivos, desenvolvimento da proposição teórica, realização da revisão bibliográfica e fundamentação teórica, escolha dos procedimentos metodológicos, coleta e análise de dados, elaboração de tabelas, gráficos e figuras, realização de cálculos e projeções, redação e adequação do manuscrito às normas da RTA.

Fernanda Cristina da Silva: Definição do problema de pesquisa e objetivos, desenvolvimento da proposição teórica, realização da revisão bibliográfica e fundamentação teórica, escolha dos procedimentos metodológicos, análise de dados, revisão crítica e redação do manuscrito.

Evandro Rodrigues de Faria: Definição do problema de pesquisa e objetivos, desenvolvimento da proposição teórica, escolha dos procedimentos metodológicos, análise de dados, realização de cálculos e projeções e revisão crítica do manuscrito. 